Discussion Papers

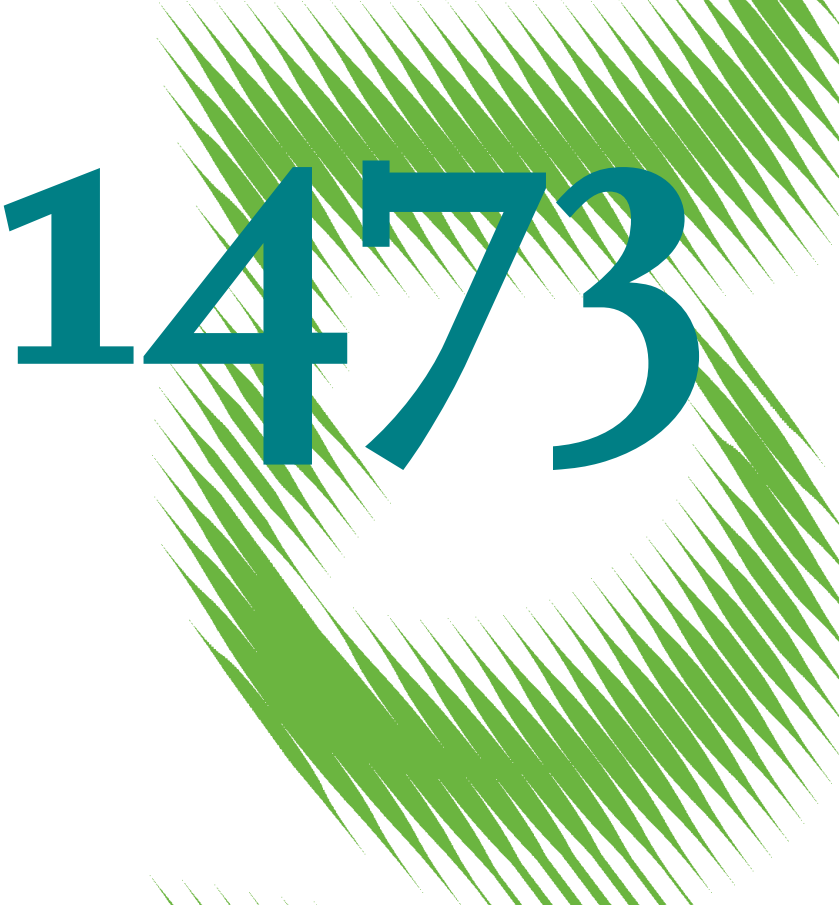

Work Creation and Rearmament in Germany 1933-1938 - A Revisionist Assessment of NS-Economic Policy Based on Input-Output Analysis 
Opinions expressed in this paper are those of the author(s) and do not necessarily reflect views of the institute.

IMPRESSUM

(C) DIW Berlin, 2015

DIW Berlin

German Institute for Economic Research

Mohrenstr. 58

10117 Berlin

Tel. +49 (30) $89789-0$

Fax +49 (30) $89789-200$

http://www.diw.de

ISSN electronic edition 1619-4535

Papers can be downloaded free of charge from the DIW Berlin website:

http://www.diw.de/discussionpapers

Discussion Papers of DIW Berlin are indexed in RePEc and SSRN:

http://ideas.repec.org/s/diw/diwwpp.html

http://www.ssrn.com/link/DIW-Berlin-German-Inst-Econ-Res.html 


\title{
Work creation and rearmament in Germany 1933-1938 - A revisionist assessment of NS-economic policy based on input-output analysis ${ }^{1}$
}

\author{
Rainer Fremdling ${ }^{2}$ \\ Reiner Staeglin ${ }^{3}$
}

\begin{abstract}
We try to measure the impact work creation programs and rearmament had on employment and production of the German economy before World War II. Theoretically based on an extended version of the conventional input-output analysis, our model or analytical framework integrates the Keynesian multiplier into Leontief's traditional model. Empirically, we apply our recently presented input-output table of Germany for the benchmark year of 1936.
\end{abstract}

Putting together the effects of both work creation proper and rearmament demonstrates that more than one million jobs were created here as early as 1933. And in 1934 and 1935, even three to four million people were employed in this manner. Several hundred thousand and later millions of jobs profited from the additional income spent on consumption. In the years from 1936 onwards, the enormous increase to five million and more for armament production alone was accompanied by additional employment and measures to restrict additional consumption.

Of course one can speculate about the counterfactual scenario of whether or not such an upswing would have taken place without Hitler's economic policy. It is true that the turning point of the business cycle had been passed in 1932, thus before Hitler had become chancellor and maybe it is also true that work creation programs and rearmament were not a necessary condition to achieve full employment as early as 1936/37. On basis of our reassessment, however, we can safely claim that they were a sufficient condition for this purpose. In more general terms, our reassessment rather supports the former view put forward, e. g. by Overy that the NS-regime introduced "a wide range of government policies designed to augment and speed up the existing recovery". We would, however, modify his chronology, that rearmament became increasingly important from 1936 onwards: rearmament actually gathered momentum as early as 1934 .

\footnotetext{
${ }^{1}$ Published first in February 2015 as Groningen Growth and Development Centre (GGDC) Research Memorandum Nr. 152: http://www.rug.nl/research/ggdc/publications/iframes/research-memoranda

${ }^{2}$ University of Groningen, Faculty of Economics and Business, P.O. Box 800, 9700 AV Groningen, The Netherlands, and DIW Berlin

${ }^{3}$ German Institute for Economic Research (DIW Berlin), Mohrenstraße 58, D-10117 Berlin, Germany
} 


\section{Introduction}

We try to measure the impact work creation programs and rearmament had on employment and production of the German economy before World War II. Theoretically based on an extended version of the conventional input-output analysis, our model or analytical framework integrates the Keynesian multiplier into Leontief's traditional open static quantity model. Empirically, we apply our recently presented input-output table of Germany for the benchmark year of 1936. ${ }^{4}$ This earliest German input-output table covers 40 economic branches/sectors, five categories of final demand and five primary inputs (see Appendix Table A1) ${ }^{5}$

In this foremost analytical paper, we cannot but cover the vast historiographic literature on the subject only selectively. ${ }^{6}$

\section{The model}

An input-output table comprehensively and quantitatively discloses interdependencies between different branches of a national economy and thus reveals the structure of an economy. This is a powerful tool to measure and thus to analyse direct and indirect effects between production and final output or employment. At the same time, it is possible to assess the impact of final demand on employment and production. The traditional Leontief-model, however, does not cover the effects induced through increased income and thus additional consumption. Keynes' theory of the multiplier deals with this phenomenon:

If final demand expands through an exogenous stimulus (e. g. additional government spending on a work creation program), cycles of spending are brought about that increase employment, production and an income that is generated in the production process. This induced income will lead to additional consumption depending on the marginal propensity to consume and the consumption pattern of private households and further to another round of spending. This circuit incorporating changes in final demand, production, income and employment is reflected in the Keynesian income multiplier. The Keynesian consumption (demand) function and thus the multiplier can be integrated into Leontief's static quantity model: ${ }^{7}$

\footnotetext{
${ }^{4}$ Fremdling/Staeglin 2014a, b. Both articles describe the table in detail. The long version comprising 112 printed pages in the Economic History Yearbook in addition offers a thorough description of sources and calculation/estimation procedures.

${ }^{5}$ This Table is only separately available in excel format. See www.ggdc.nl research memorandum nr. 152, Fremdling/Staeglin 2015.

${ }^{6}$ For a comprehensive treatment in English see the book by Silverman (1998); furthermore James (1986) and Cohn (1992). Most of the relevant literature written in German is only touched upon in the following footnotes and the bibliography. We refrain entirely from discussing issues of the so-called "Borchardt debate", i. e. an evaluation of chancellor Brüning's austerity policy. On this see e.g. the English articles in the book edited by von Kruedener (1990).

${ }^{7}$ For details of the model and its application, see Stäglin/Pischner (1976 a) and Stäglin et al. (1976 b).
} 
Leontief model (L):

$\mathrm{x}_{\mathrm{L}}=(\mathrm{I}-\mathrm{A})^{-1} \cdot \mathrm{y}$

$\mathrm{e}_{\mathrm{L}}=1 \cdot \mathrm{x}_{\mathrm{L}}$

Leontief model and Keynesian (multiplier) model (K) combined:

$\mathrm{x}_{\mathrm{L}+\mathrm{K}}=(\mathrm{I}-\mathrm{M})^{-1} \cdot \mathrm{y}$

$(\mathrm{I}-\mathrm{M})^{-1}=(\mathrm{I}-\mathrm{A})^{-1} \cdot(\mathrm{I}-\mathrm{D})^{-1}$

$\mathrm{e}_{\mathrm{L}+\mathrm{K}}=1 \cdot \mathrm{x}_{\mathrm{L}+\mathrm{K}}$

where

$\mathrm{D}=\mathrm{W} \cdot \mathrm{A}_{\mathrm{v}}$

$\mathrm{W}=\mathrm{W}_{1} \cdot \mathrm{W}_{2}$

$A_{v}=A_{g} \cdot(I-A)^{-1}$

$\mathrm{M}=\mathrm{A}_{\mathrm{g}}+\mathrm{W} \cdot \mathrm{A}_{\mathrm{v}}$

Matrix or vector of:

$\mathrm{A}=$ input coefficients

$\mathrm{I}=$ unity matrix

$\mathrm{y}=$ exogenous final demand

$\mathrm{A}_{\mathrm{g}}=$ direct primary input coefficients for gross production

$A_{v}=$ direct and indirect primary input coefficients for value added or income

$\mathrm{D}=$ induced additional private consumption

$\mathrm{x}=$ direct production

$\mathrm{x}_{\mathrm{L}}=$ induced direct and indirect production based on the Leontief model

$\mathrm{x}_{\mathrm{L}+\mathrm{K}}=$ induced direct and indirect production based on the Leontief and Keynesian model

combined

$1=\mathrm{e} / \mathrm{x}$ labour coefficient (labour output ratio)

$\mathrm{e}=$ direct employment

$\mathrm{e}_{\mathrm{L}}=$ induced direct and indirect employment based on the Leontief model

$\mathrm{e}_{\mathrm{L}+\mathrm{K}}=$ induced direct and indirect employment based on the Leontief and Keynesian model

combined

$\mathrm{W}_{1}=$ expenditure structure of additional private consumption

$\mathrm{W}_{2}=$ share of value added or income used for additional private consumption

$\mathrm{W}=$ weighted additional private consumption

$\mathrm{M}=$ modified primary input coefficients

$\mathrm{I}-\mathrm{A}=$ Leontief matrix

$(\mathrm{I}-\mathrm{A})^{-1}=$ production multiplier (Leontief inverse)

$(\mathrm{I}-\mathrm{D})^{-1}=$ private consumption multiplier ("Keynes" inverse)

$(\mathrm{I}-\mathrm{M})^{-1}=$ production and private consumption multiplier (extended inverse)

\section{Input-output table}

The matrix of input coefficients (A) of 40 branches is directly derived from the first quadrant of the input-output (I-O) table by dividing input values by gross production values (row 1-45). The matrix of primary input coefficients for gross production $\left(\mathrm{A}_{\mathrm{g}}\right)$ is calculated in a similar way by dividing the values in the rows 41 to 45 by gross production values. 
For applying the input-output analysis to military spending, the basic data of the input-output table had to be rearranged: to isolate the effects of rearmament, the government sector was split up into civilian (non-military) and military spending. The civilian part of government activity remained in quadrant I of the input-output table whereas military expenditure became a separate vector in quadrant II, i. e. part of final demand. By this operation, both government components were artificially separated into an exogenous (military) and an endogenous (civilian) category within the input-output table. Employment in the government sector was split up as well to get an appropriate labour coefficient or labour output ratio (l). Table 8 presents our basic data on government expenditure in total and on military, in particular.

\section{Final demand}

\section{Work creation programs}

From the first, work creation programs have been closely associated with Hitler's government. He became German chancellor on 30. 1. 1933. This year witnessed high unemployment and investment at an extremely low level which not even covered the amount necessary to compensate for wear and tear (depreciation). ${ }^{8}$ One should keep in mind, however, that measures against the till then unknown economic slump had been initiated before that year and that the turning point of the business cycle had been surpassed 1933 as well. ${ }^{9}$ But the work creation programs proper did not get momentum before Hitler's government came into power. ${ }^{10} \mathrm{We}$ thus concentrate on the three years from 1933 to 1935 , when most of the money or funds were spent for this purpose. ${ }^{11}$ Based on Grebler (1937)

\footnotetext{
${ }^{8}$ Abelshauser 1999, p. 505. A report by the German Statistical Office (Statistisches Reichsamt, StRA) for the Minister of Economics classified as "confidential" was compiled in 1938 (BA R3102 2700, April 19, 1938). It revealed that in 1933 only "new" public investment bore a plus-sign, which indicated a growing public capital stock. See as well StRA 1935, p. 689. For time series on investment figures, see StJR 1938, pp. 539 f.; StH1949, p. 604; Ritschl 1992, p. 160.

${ }^{9}$ Borchardt 1984; Spree 2004 and Buchheim 2008. The argument can be based on figures collected by the German Institute for Business Research (Institut für Konjunkturforschung, IfK), renamed as German Institute for Economic Research (Deutsches Institut für Wirtschaftsforschung, DIW) from 1941 onwards (Stäglin/Fremdling 2015). Between 1928 and 1932, the IfK was in charge of the Industrial Reporting System (Industrieberichterstattung) and thus gathered information on employment and work capacity from selected industrial firms (Gierth 1941). The monthly figures on total hours worked in percent of workplace capacity of industry (Arbeitsvolumen: geleistete Arbeisstunden in Prozent der Stundenkapazität) show a trough of the business cycle in 1932 and a clear upswing from January 1933 onwards. For corresponding monthly figures on more than 100 industrial branches, also see Wagemann 1935, pp. 1745. Using a different method, i. e. an autoregressive model, Ritschl (2003, pp. $134 \mathrm{ff}$.) drew the same conclusion. Abelshauser (1999, p. 505), however, doubts this proposition.

${ }^{10}$ See details about the timing and the amount of these measures in Grebler 1937, pp. 418-421; Schiller 1936, pp. 54
ff.; for a description and discussion of the programs, see as well Kroll 1958, especially chapters 10 to 13 .

${ }^{11}$ For the sake of simplicity we do not distinguish between direct (unmittelbare) and indirect (mittelbare Arbeitsbeschaffung) work creation programs. We assume that indirect measures such as tax vouchers (Steuergutscheine) created funds of the same size for spending. Other indirect measures like increased allowance for depreciation of newly purchased equipment, however, are not included in the figures of the I-O analysis. Holtfrerich emphasized the impact of this measure (100\% immediate depreciation of investment) in his criticism of a book by Harold James (Holtfrerich 1992, p. 500). Schröder discussed the rules of depreciation in the 1934 tax reform in detail: $100 \%$ immediate depreciation for investment goods with a lifetime of less than five years (Abschreibungsfreiheit für kurzlebige Wirtschaftsgüter) and for replacement investment (Sofortabschreibung von Ersatzbeschaffung), even in retrospect for these expenses before 1934, see Schröder 1996, pp. 73-80, 132 ff.
} 
Buchheim (2008, Tabelle 3, p. 391) conveniently summarized the 12 programs specifying the amount and the year of spending of these funds. Not all of these measures truly qualified as additional spending for a specific work creation program. ${ }^{12}$ Our reassessment of the policy therefore inevitably contains some speculative elements. Several of the twelve work creation programs bore labels in rather general or meaningless terms (e. g. Sofortprogramm, sonstige Massnahmen) or (Papen, Reinhardt), which do not allow to assign them properly to economic activities or areas of spending. ${ }^{13}$ We drew on Schiller's detailed tables for 1933 and 1934 on the amounts granted for specific purposes. ${ }^{14}$

\footnotetext{
${ }^{12}$ E. g. investment of railways which would have been carried out anyway or spending on rearmament. See Schiller (1936, p. 82 ff.); Grebler (1937, pp. 428 ff.); Buchheim (2008, pp. 395 f.). See also Ritschl (2003, pp. 130 ff.) who put forward that not all work creation programs were financed through deficit spending. Ritschl analyzed the impact on additional employment, and he also examined as to what extent those programs could be considered as truly "Keynesian".

${ }^{13}$ There is a vast literature describing these programs in detail, thus we refrain from repeating easily available information. For details of these programs see among others Spree 2004, pp. 112 ff. and Spoerer/Streb 2013, pp. $104 \mathrm{ff}$.

${ }^{14}$ Schiller 1936, pp. 158 f. Based on this information we compiled a suitable percentage distribution according to purposes. Schiller's detailed account covers the years of 1933 and 1934, referring to "granting" (Bewilligung) the funds, not to spending it. For 1935, we used the average percentage distribution of the two preceding years. Railways (Reichsbahn), the post office (Reichspost) and the motorways (Reichsautobahnen) were treated separately.
} 
Table 1: Work creation programs and assignment to purposes/branches of spending - Germany 1933-1935

\begin{tabular}{|c|c|c|c|c|c|}
\hline \multirow{2}{*}{$\begin{array}{l}\text { Work creation programs } \\
\text { (purpose/area of spending) }\end{array}$} & \multicolumn{3}{|c|}{ Year } & \multicolumn{2}{|c|}{$\begin{array}{c}\text { Split-up (col.) by and assigned to delivering } \\
\text { branches (rows) of the }\end{array}$} \\
\hline & $\begin{array}{c}1933 \\
\text { m RM }\end{array}$ & $\begin{array}{c}1934 \\
\text { m RM }\end{array}$ & $\begin{array}{c}1935 \\
\text { m RM }\end{array}$ & $\begin{array}{l}\text { Investment matrix } \\
\text { branch number* }\end{array}$ & $\begin{array}{l}\text { I-O table } \\
\text { column, row }\end{array}$ \\
\hline Öffentlicher Bau (ohne Versorgungsbetriebe) & 276 & 406 & 167 & & row 31 \\
\hline Versorgungsbetriebe & 70 & 88 & 39 & col. 32 & rows $9,10,12$ \\
\hline Wohnungsbau & 292 & 632 & 223 & & row 31 \\
\hline Melioration, Flussregulierung & 130 & 166 & 73 & & row 31 \\
\hline Landwirtschaftschaftliche Siedlungen, Gehöfte & 5 & 22 & 6 & & row 1 \\
\hline Fischerei (Heringsloggerbau, Fischdampfer) & 2 & 4 & 1 & & row 10 \\
\hline Konsumförderung (Bedarfsdeckungsscheine) & 28 & 35 & 16 & & col.41 (rows $12,14,19)$ \\
\hline Grundförderung (einschließlich Arbeitsdienst) & 66 & 281 & 81 & & row 39 \\
\hline Allgemeine Maßnahmen Reichsbahn, Schiffahrt etc. & 83 & 114 & 49 & col. 35 & rows $9,10,11,12,31$ \\
\hline Reichsbahn & 530 & 461 & & col. 35 & rows $9,10,11,12,31$ \\
\hline Reichspost & 65 & 46 & & col. 35 & rows $9,10,11,12,31$ \\
\hline Reichsbautobahn & 8 & 194 & 148 & & row 31 \\
\hline Total spending (m RM) & 1555 & 2449 & 804 & & \\
\hline
\end{tabular}

* For the numbers of the branches see Tables 2, A1, A2.

Sources and notes:

I-O table: Fremdling/Staeglin 2014a or b.

Investment matrix: Stäglin 2013 or Fremdling/Staeglin 2014a, pp. 254 f.

The amount of total spending is based on Buchheim/Grebler (Buchheim 2008, p. 391 Tabelle 3).

The allocation among purposes/areas ("Sachverwendungszwecke" except railway, post office and motorways) is based on Schiller (1936, pp. 158 f.).

In a first step, we allocated total spending derived from Buchheim's table for the programs (Maßnahmen no. 1-8, 12) according to the percentage distribution calculated from Schiller's figures (see Table 1). The amounts spent on Germany's railways (Reichsbahn no. 9), post office (Reichspost no. 10) and the famous motorways (Reichsautobahnen no. 11) were directly inserted into Table 1.

In a second step, we decided on which branches of the economy the money was spent in the first round. We selected those specific branches from our I-O table which presumably would have met the demand. Technically, we constructed a vector of final demand which complies with the delimitation of the I-O table. The numbers of the rows of Table 2 refer to the corresponding rows of the I-O table. The numbers of the columns either refer to a column of our investment matrix (see appendix Table A2) ${ }^{15}$ or a column of the I-O table: they indicate that a specific amount of a work creation program had to be assigned to several branches. ${ }^{16}$ In order to split this amount up the figures of the investment matrix or I-O table were used to generate a percentage distribution for the allocation. Accordingly, we assigned the funds (grants) of the work creation programs to specific branches of the I-O table. For 1933 to 1935, we thus compiled three vectors of final demand (y). They are shown in Table 2.

\footnotetext{
${ }^{15}$ This Table is only separately available in excel format. See www.ggdc.nl research memoranda Fremdling/Staeglin 2015.

${ }^{16}$ Our selection did not cover all entries (inputs) of a specific branch (column). The demand of the first round was thus deliberately concentrated on the most important delivering branches. Furthermore, we refrained from adjusting for trade margins and transport charges. This procedure underlines the partially hypothetical character of our reasoning.
} 
Table 2: Spending for work creation assigned to branches of the I-O table - Germany 1933-1935

\begin{tabular}{|c|c|c|c|c|}
\hline \multirow{3}{*}{ Number } & \multirow{3}{*}{ Branch of the I-O table } & \multicolumn{3}{|c|}{ Year } \\
\hline & & 1933 & 1934 & 1935 \\
\hline & & $\mathrm{m} \mathrm{RM}$ & $\mathrm{m} \mathrm{RM}$ & $\mathrm{m} \mathrm{RM}$ \\
\hline 1 & Agriculture & 4.6 & 22.0 & 6.2 \\
\hline 9 & Machinery & 56.3 & 59.4 & 15.1 \\
\hline 10 & Constructional steel & 125.8 & 119.8 & 13.7 \\
\hline 11 & Vehicles and aerospace & 66.9 & 61.3 & 4.8 \\
\hline 12 & Electrical engineering & 107.3 & 113.1 & 28.8 \\
\hline 14 & Metal products & 6.1 & 7.4 & 3.4 \\
\hline 19 & Manufactured wood products & 19.3 & 23.6 & 10.6 \\
\hline 31 & Building and construction & 1102.4 & 1761.7 & 639.9 \\
\hline \multirow[t]{2}{*}{39} & Other services & 66.3 & 280.6 & 81.5 \\
\hline & Total spending (m RM) & 1555.0 & 2449.0 & 804.0 \\
\hline
\end{tabular}

Sources and notes: See text.

I-O table: Fremdling/Staeglin 2014a or b.

Investment matrix: Stäglin 2013 or Fremdling/Staeglin 2014a, pp. 254 f.

The amount of total spending is based on Buchheim/Grebler (Buchheim 2008, p. 391 Tabelle 3).

The allocation among purposes/areas ("Sachverwendungszwecke" except railway, post office and motorways) is based on Schiller (1936, pp. 158 f.).

\section{Rearmament}

The vector of final demand for military outlays in 1936 is part of our adapted I-O table of 1936, where government spending was split up into civilian and military spending (see Table 8 for the values). We extended our analysis of German rearmament beyond the benchmark year of 1936 by applying the same methodology to the entire decade of the 1930s, the crucial period before the Second World War: we drew on figures of military expenditure compiled by Oshima for the fiscal years 1932 to $1939 .{ }^{17}$ In order to assign this spending to the sectors of our input-output table we used the same percentage distribution as for the calendar year of 1936. In this way we got eight vectors of final demand (y) concerning rearmament (see Table $10)$.

\section{Impact of work creation programs}

We proceeded in the following way: based on the input coefficients of our input-output table for 1936 of 40 sectors (A) we calculated the inverted Leontief matrix (I-A) ${ }^{-1} .{ }^{18}$ After multiplying it by the vectors of final demand $(y){ }^{19}$ we obtained the direct and indirect

\footnotetext{
${ }^{17}$ Oshima 2006, p. 182, fiscal year april to march. Oshima's figures comply with similar numbers reported by Boelcke (1985, pp. 28, 51) and Klein (1948, p. 68). In a refined version of our estimate, Oshima's figures will be assigned to the calendar year and adjusted for imports (1\% in 1936) and wages/salaries of soldiers/civilian personnel (7\% in 1936).

${ }^{18}$ An input-output analysis usually applies a table constructed for a certain year to the preceding and the following years as well. It is assumed that for the medium term structural relations within an economy are rather stable. This holds true especially for our 1936 table: in compiling the table we also used structural relations of neighbouring years, e.g. results of the 1933 industrial census. See Fremdling/Staeglin (2014 a).

${ }^{19}$ See Table 1 for the values. The values were assigned to the proper rows of the input-output table, see Table 2 and the corresponding vector for 1934 in Table 4 (third column).
} 
(Leontief) effects of the work creation programs on production for the three years of 1933, 1934 and 1935 (see Table 3 for the aggregate and Table 4 for sectoral ${ }^{20}$ results). The direct effects are the values, i. e. initial spending, of the final demand vectors (Table 2). Multiplying this initial spending by the labour output ratio $(1=$ labour coefficients) of each sector (number of workers per output of one million RM $)^{21}$ yielded the direct employment effects. Similarly, the impact both on direct and indirect (Leontief) employment was obtained by multiplying the labour coefficients by the vectors of direct and indirect production effects combined (see Tables 3 and 4). This matrix algebra solely provided the indirect effects based on the Leontief model. For the Keynesian extension of our model, a vector of the consumption pattern was needed: based on our consumption matrix ${ }^{22}$ we compiled the figures shown in Table 4 , column 2 (w1). We lightly adjusted the structure of consumption by dropping items related to higher income households. ${ }^{23}$ In addition to the structure of consumption, we had to assume as to what extent the additional income was spent on consumption. Besides the marginal propensity to consume balancing effects had to be taken into account. For this purpose, an almost forgotten calculation by the German Statistical Office in 1933 was very helpful. ${ }^{24}$ The StRA distinguished between two different types of work creation programs: firstly arbeitsintensive programs demanding a high input of labour and secondly materialintensive programs demanding a high input of material. With this distinction in mind the StRA put forward a Keynesian type of reasoning about the secondary effects of government spending on work creation (as soon as in 1933). Displayed numerically and graphically, the StRA presented 12 rounds of circular spending via the income multiplier. It took into account that those people getting work through this measure did not claim unemployment money or any other pecuniary help from the government any more. Furthermore, the StRA reckoned that the government could profit from additional taxes and contributions to social security schemes. In analogy to the StRA, we allowed for these balancing effects and assumed rather low spending shares (w2) in two variants: ratios of 0.5 or 0.45 for dependent households and for entrepreneurs 0.5 and $0.3 .^{25}$ Thus we got two different Keynesian private consumption multipliers depending on our assumed spending shares: $\mathrm{D}_{1}(0.5$ and 0.5$)$ and $\mathrm{D}_{2}(0.45$ and 0.3$)$. Table 3 shows our aggregate results of analysing the impact of work creation on the German economy between 1933 and 1935.Table 4 complements the results by a sectoral breakdown for 1934 both for production and employment. Due to our assumptions, the same structural relations hold true for the other two years in question, 1933 and 1935.

\footnotetext{
${ }^{20}$ We put forward the sectoral distribution only for one year, i. e. 1934. This is justified because we stuck to the same structural relations (i. e. fixed coefficients and labour output ratios) for all years.

${ }^{21}$ See the first column in Table 4.

${ }^{22}$ See Table 4-16 in Fremdling/Staeglin 2014 a, p. 248.

${ }^{23}$ We still covered more than 70 percent of private consumption at purchasers' prices in 1936 . For our subsequent calculation, we used as well a consumption vector at producers' prices. A sensitivity analysis revealed, however, that the difference in prices did not matter, thus we do not depict these results.

${ }^{24}$ Statistisches Reichsamt 1933.

${ }^{25}$ Technically we assigned 0.5 and 0.45 to "Compensation of employees" and 0.5 and 0.3 to "Mixed income/operating surplus" in the matrix of primary inputs, whereas the other primary inputs were set at zero.
} 
Table 3: The impact of work creation programs on employment - Germany 1933-1935 Number of people employed

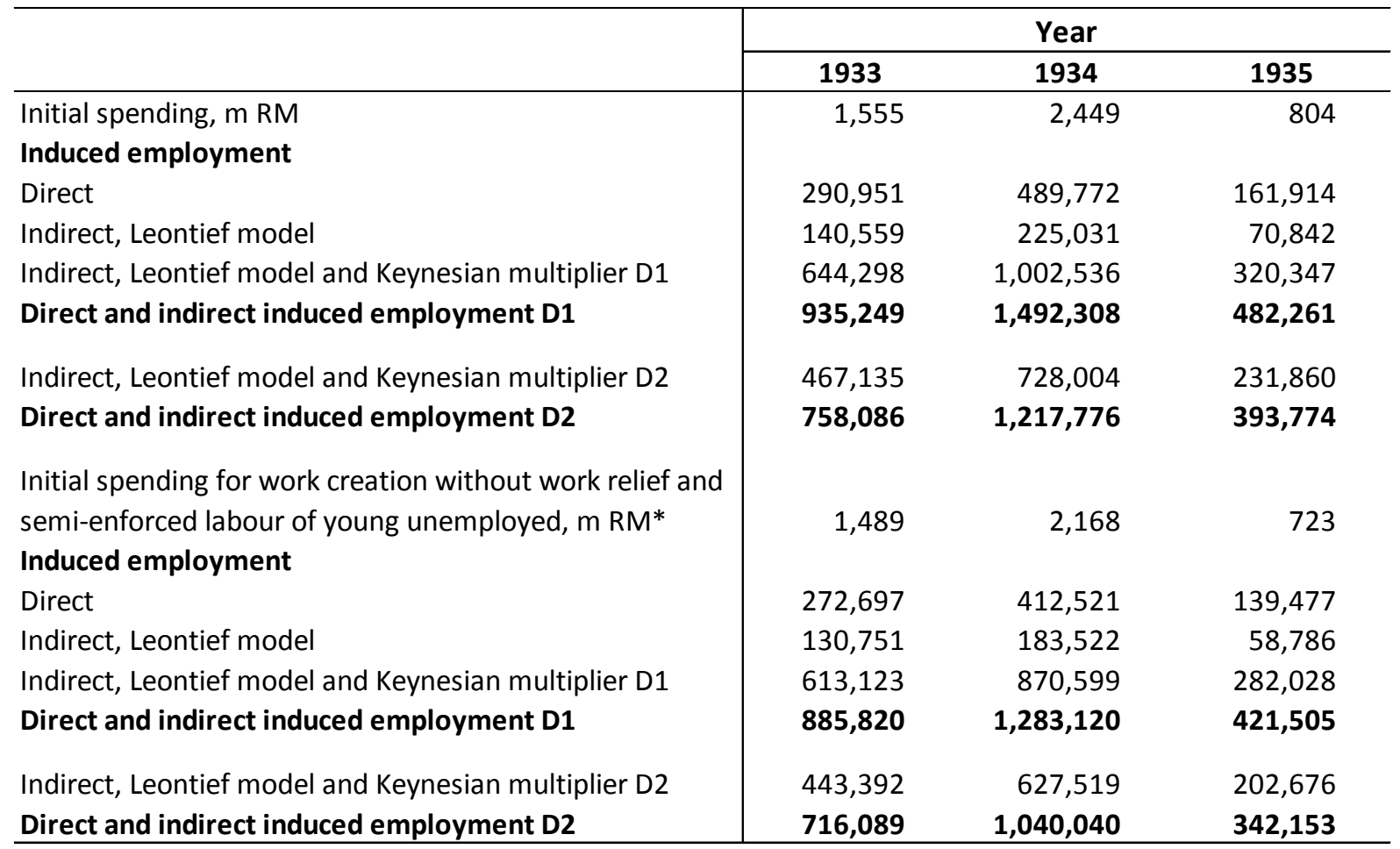

* See section VI and Table 6 .

Source: See text. 
Table 4: Impact of work creation on production and employment in Germany 1934

$\mathrm{m} \mathrm{RM}$ and number of people employed

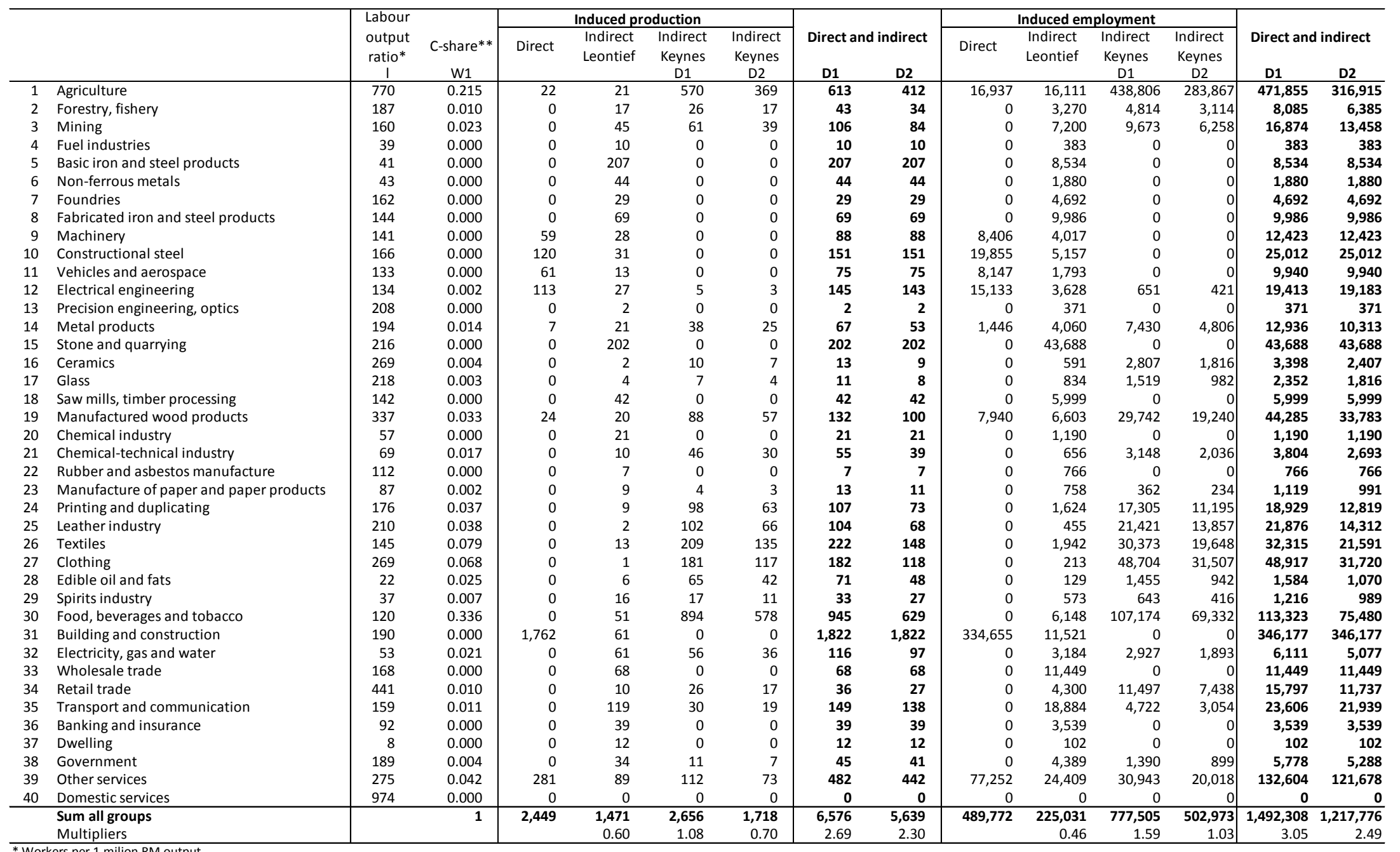

milion RM outpu

For employment figures see Table 1 . 
The work creation programs generated nearly three hundred thousand work places in 1933 directly and half a million in 1934 before the number dropped significantly to 162 thousand in 1935. In addition, our method revealed a substantial indirect increase of work creation by nearly fifty percent through Leontief-type linkage effects and even more via the Keynesian multiplier: a higher propensity to consume (D1) resulted in a multiplier of 1.6, a lower one (D2) still generated a multiplier of 1.0. Indirectly induced employment altogether increased the amount of workplaces by a factor of two (D1) or 1.5 (D2) (see Table 4). If both direct and indirect effects as revealed by our model are taken together (see Table 3 ) the work creation programs proper created up to one and a half million jobs in 1934 (D1) and at least 400 thousand ones in 1935 (D2). Concerning production (see the last row of Table 4) the Leontief linkage effects are higher and the Keynesian multiplier effects are lower than the indirect effects on employment. These differences are due to a different labour productivity of those industries/sectors which profited from the work creation programs.

It is thus helpful that our method also allows to detect those branches which profited most from indirect effects. Besides domestic services all other branches were involved by Leontief linkages. Concerning both production and employment, these indirect effects were most powerful in quite a number of branches closely linked to the production of producer goods namely mining; basic iron and steel; fabricated iron and steel products; stone and quarrying; saw mills and timber processing; food, beverages and tobacco; wholesale trade and transport and communication. Due to the pattern of our consumption function, the Keynesian multiplier effects were widespread on the one hand but mainly concentrated on those branches closely related to the demands of private households namely agriculture; manufactured wood products; printing and duplicating; leather industry; textiles; clothing; food, beverages and tobacco and retail trade.

\section{Evaluation of work creation programs}

At first sight, our results seem to corroborate findings which put forward the rather modest impact of these work creation programs e. g. by Buchheim (2008) and Ritschl (2003). ${ }^{26}$

Ritschl (2003) concluded "that public deficits were too small to account for the speed of recovery between 1933 and 1936". By applying an autoregressive model he predicted in retrospect: "An upswing under selffulfilling expectations would have had exactly the same vigor without Hitler and without deficit spending."

Buchheim (2008, p. 392) supported his own view by quantifying the direct effects of the work creation programs. He referred to Grebler $(1937$, p. 822) and even overestimated the direct impact: based on the assumption of 2000 RM per workplace and year Buchheim divided the entire amount of roughly 1.5 billion RM spent on work creation in 1933 by this yearly rate for employing one worker. In this way he estimated that in 1933 between 700,000 and 800,000 additional work places for one year were, or could have been, created. The reasoning is

\footnotetext{
${ }^{26}$ See also Spoerer 2005 and Spoerer/Streb 2013, pp. 104 ff.; for a summary account, see Spree (2004, pp. 122 ff.), who among others refers also to the controversial views between Borchardt and Wehler. Spree himself (2004, p. 126) favoured Ritschl's claim that economic recovery from the fall of 1932 onwards didn't succeed because of but rather in spite of Nazi-usurpation of political power in Germany.
} 
flawed, however: although Grebler arrived at about the same figure, he made clear that this figure of $2000 \mathrm{RM}$ only applied to those works for which the public administration entirely financed the work program and he should have added, for which no significant additional costs were involved in getting people to work. This latter assumption probably held true for the publicly sponsored relief or emergency works (Notstandsarbeiten) but not for regular employment in established firms. The funds of the work creation program were not solely spent on wages but on purchases from other firms at their selling price, i. e. the turnover or gross production value: it comprised value added (wages and profits) and costs of inputs from other firms.

In Table 5 we calculated figures of gross production, gross value added and gross wage per person employed for those branches for which we imputed the spending on work creation. Dividing gross production value per worker through Grebler's 2000 RM indicates how many times this amount would have had to be spent in order to create one workplace in a particular industry directly (workplace ratio): neglecting trade charges and transportation costs, more than three times for the average of the entire economy (without agriculture) and about the same for the branches 9,10,11 and 12. In all the other branches the ratio is lower and in agriculture the $2000 \mathrm{RM}$ even would have sufficed to induce more than one work place. This outcome highly correlates with labour productivity (GVA per worker) and average wage per branch.

Table 5: Gross production (GP), gross value added (GVA) and gross wage (GW) per person employed - Germany 1936

in RM

\begin{tabular}{|c|c|c|c|c|c|}
\hline Number & Branch of the $\mathrm{I}-\mathrm{O}$ table & GP & GVA & GW & $\begin{array}{c}\text { workplace ratio } \\
\text { GP/2000 RM }\end{array}$ \\
\hline 1 & Agriculture & 1,300 & 946 & & 0.6 \\
\hline 9 & Machinery & 7,069 & 4,020 & 2,075 & 3.5 \\
\hline 10 & Constructional steel & 6,035 & 3,050 & 1,801 & 3.0 \\
\hline 11 & Vehicles and aerospace & 7,530 & 3,180 & 1,903 & 3.8 \\
\hline 12 & Electrical engineering & 7,473 & 4,101 & 2,146 & 3.7 \\
\hline 14 & Metal products & 5,148 & 2,773 & 1,355 & 2.6 \\
\hline 19 & Manufactured wood products & 2,969 & 1,718 & 774 & 1.5 \\
\hline 31 & Building and construction & 5,264 & 3,800 & 1,494 & 2.6 \\
\hline \multirow[t]{2}{*}{39} & Other services & 3,632 & 2,069 & 1,018 & 1.8 \\
\hline & Entire economy without agriculture & 6,370 & 3,230 & 1,492 & 3.2 \\
\hline
\end{tabular}

Source: Appendix Table A1 and number of people employed, see Fremdling/Staeglin 2014a, p. 290.

Other than Buchheim/Grebler, we had these caveats in mind when we applied the labour output ratio (labour coefficient) to these work creation programs. Of course we got significantly lower figures for direct employment than Buchheim/Grebler had estimated (290 thousand in 1933, see Table 3; for the labour output ratio see Table 4).

On the other hand, work creation programs under the label of Notstandsarbeiten (relief works) or the Arbeitsdienst (semi-enforced labour) provided work for quite a lot of people explicitely not yet included in our analysis (see Table 6): After the First World War, the wertschaffende Arbeitslosenfürsorge (emergency work) was introduced. ${ }^{27}$ From 1927

\footnotetext{
${ }^{27}$ Petzina et al. 1978, p. 122; Schiller 1936, pp. 35 ff., 53 ff.; Syrup 1936, pp. 56 f., 77 ff.
} 
onwards, it was financed by the work exchange, and thus became a substitute for the payment of unemployment money (Syrup 1936, p. 134). In addition, a voluntary labour service was introduced in 1931 for unemployed young people. ${ }^{28}$ People engaged in this kind of work lived in camps and were mainly employed for cultivating soil (Landeskulturarbeiten) and increasingly for harvesting (Einsatz bei landwirtschaftlichen Erntenotständen). ${ }^{29}$ Grebler's 2000 RM surely would have sufficed to cover board and lodging, some cash payment (pocket money) and even simple tools. Probably this figure is still too high if one follows the reasoning of the German Statistical Office which calculated 1200 RM per workplace for these programs in $1933 .^{30}$ This type of work, however, presumably had barely any additional backward linkage effects on other branches of the economy. ${ }^{31}$

It is not clear as to what extent these measures of creating cheap work are comprised in our I$\mathrm{O}$ analysis. ${ }^{32}$ Some money for this kind of work is included in Table 1 under the heading of Grundförderung (einschließlich Arbeitsdienst). The amount spent is too low for financing all the labour approximately engaged in the programs 1 to 3 listed in Table 6 . The bulk of these people was either financed by the other programs (Table 1) or by additional funds not yet dealt with. According to Grebler (1937, pp. 421 f.) Arbeitsdienst and Landhilfe, Landjahr were not included in the work creation programs proper. The Institute for Business Cycle Research (IfK) distinguished between regular and additional employment (zusätzliche Beschäftigung). The figures for additional employment match rather well with the comparable numbers derived from other sources (see rows 4 and 4 a of Table 6).

\footnotetext{
${ }^{28}$ The "Reichsarbeitsdienst", a compulsory or semi-enforced labour service of young women and men, continued this program from 1934/35 onwards. In 1936/37, this workforce was planned to comprise 230,000 men. The labour service of women remained small, about 10,000 at any time around 1936, whereas more than 200,000 men were concerned before 1936 (Patel 2005, pp. 106, 121 ff., 137 ff.). In 1936, the actual workforce included between 183,968 (February) and 206,648 (April) men and between 9,508 (October) and 12,186 (April) women. (Statistisches Reichsamt 1938, pp. 126-130).

${ }^{29}$ Syrup 1936, p. 76; Schiller 1936, p. 54.

${ }^{30}$ See the detailed table for arbeitsintensive Arbeitsbeschaffung (work intensive programs), Statistisches Reichsamt 1933, p. 3.

${ }^{31}$ Without this work the young people would have had to receive some money anyway: $600 \mathrm{RM}$ as unemployment money (Arbeitslosenhilfe), see Statistisches Reichsamt 1933, p. 2; Schiller 1936, p. 35 ff.

${ }^{32}$ From 1932/33 onwards, the wertschaffende Arbeitslosenfürsorge (emergency work) was partly (Restfinanzierung) financed by funds from the work creation programs proper. See Schiller 1936, p. 36 ff.
} 
Table 6: People employed through work creation programs - Germany 1933-1935

\begin{tabular}{|c|c|c|c|c|}
\hline \multirow{4}{*}{ 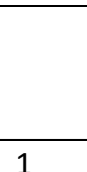 } & \multirow{3}{*}{ Program } & \multicolumn{3}{|c|}{ Year } \\
\hline & & 1933 & 1934 & 1935 \\
\hline & & \multicolumn{3}{|c|}{ yearly number of persons employed } \\
\hline & Relief works (Notstandsarbeiten) & 161,423 & 390,986 & 217,434 \\
\hline 2 & "Arbeitsdienst" & $200-250,000$ & $200-250,000$ & 200,000 \\
\hline 3 & "Landhilfe, Landjahr" & $?$ & 150,000 & 150,000 \\
\hline 4 & Approximation subtotal 1-3 & 500,000 & 800,000 & 550,000 \\
\hline $4 a^{*}$ & 1 - 3 IfK-data & 550,000 & 790,000 & $620,000 * *$ \\
\hline $5 a$ & I-O analysis D1 & 935,249 & $1,492,308$ & 482,261 \\
\hline $5 b$ & I-O analysis D2 & 758,086 & $1,217,776$ & 393,774 \\
\hline $6 a$ & I-O analysis without "Grundförderung"*** D1 & 885,820 & $1,283,120$ & 421,505 \\
\hline $6 b$ & I-O analysis without "Grundförderung"*** D2 & 716,089 & $1,040,040$ & 342,153 \\
\hline $7 a$ & Approximation total $4+6 a$ & $1,400,000$ & $2,100,000$ & $1,000,000$ \\
\hline 7b & Approximation total $4+6 b$ & $1,200,000$ & $1,800,000$ & 900,000 \\
\hline 8 & Registered unemployed dependent workers & $4,800,000$ & $2,718,000$ & $2,151,000$ \\
\hline
\end{tabular}

* Calculated from monthly data of "Zusätzliche Beschäftigung" (Landhelfer, Notstandsarbeiter, Arbeitsdienst, Fürsorgearbeiter).

** January - July.

*** Without "Grundförderung (einschließlich Arbeitsdienst)" in Table 3.

Sources: 1 + 8 Petzina et al. (1978, pp. 122, 119); 2 + 3 Grebler (1937, p. 822); 4a Institut für Konjunkturforschung (IfK) 1935, p. 152; $5 a-6 b$ see Table 5.

In order to avoid double counting of cheap relief work in our I-O analysis, we dropped the funds spent for "Grundförderung" 33 from our calculation (see Table 6, rows 6a, b and Table 3 ). As shown in Table 3, these funds had a rather modest impact on direct and indirect work creation. In rows $7 \mathrm{a}, \mathrm{b}$ of Table 6 , we calculated an approximation of the total labour force engaged directly and indirectly in some kind of work creation program. With all the caveats in mind, it seems pretty clear that these aggregates for the years 1933 to 1935 are an upperbound estimates because probably the figures still contain some double counting. Thus far there is no clear-cut evidence to avoid this bias. Compared with the registered unemployed, those, who got work through the programs referred to, made up nearly twenty percent in 1933, more than fifty percent in 1934 and more than one fifth in 1935 (row 5a of Table 6). ${ }^{34}$ The decrease of registered unemployed dependent workers (row 8 of Table 6 ) is in line with the numbers created by any kind of work creation (rows 7a, b of Table 6).

Although our findings are biased upwards it seems difficult to maintain the proposition that the work creation programs had a rather modest impact on employment. All the less as we did not yet account for the impact of rearmament on employment.

Thus to some extent our findings support the views put forward by Abelshauser ${ }^{35}, \mathrm{Cohn}^{36}$ and

\footnotetext{
${ }^{33}$ According to Schiller (1936, p. 38 ff.) it is not clear as to what extent emergency works were financed through additional, credit financed funds. The basic funds, thus the Grundförderung, were financed by detained unemployment compensation (Unterstützungsersparnisse). The work exchange, however, refused to finance private enterprises and single communities by this measure. Syrup 1936, p. 134, 168.

${ }^{34}$ The officially registered unemployment figures refer to compulsorily health-insured dependent workers only (Arbeiter and Angestellte, Syrup 1936, pp. 161 f.). Thus this limited group among others did not cover hidden unemployment in agriculture and self-employed people out of business.

35 "Der Erfolg [Vollbeschäftigung im Laufe des Jahres 1936] wurde von der öffentlichen Meinung - durchaus zu Recht - der NS-Krisenpolitik gutgeschrieben." (According to Abelshauser public opinion ascribed the success of achieving full employment in 1936 - "quite rightly" - to the economic policy of the NS- regime). Abelshauser 1999, p. 511.
} 
Overy $^{37}$. Spree (2004, p. 122) neatly presented a brief juxtaposition of the two conflicting views (Abelshauser versus Buchheim) on the effects of work creation. ${ }^{38}$

Our I-O analysis catches pretty well the direct and indirect impact of the work creation programs through the interrelated production process covered in the first quadrant of the I-O table (Leontief effects). It furthermore reflects the secondary effects generated through additional income and thus increased private consumption (Keynes multiplier). In this interim evaluation, we can as well compare our results with similar attempts to calculate or rather assume the size of a Keynesian-type multiplier.

Here the study conducted by the German Statistical Office (Statistisches Reichsamt) as early as in 1933 is helpful: by way of example and based on sound empirics, it calculated the secondary effects of work creation including e. g. additional income, increased state revenues, decreased unemployment compensation and increased savings. ${ }^{39}$ The StRA applied the same reasoning which later became known as the Keynesian multiplier. Without putting forward the sophisticated assumptions and the four alternative calculations in detail here the StRA arrived at multipliers within the range of 2.3 to 3.7 for government spending and 1.3 to 3.6 for job creation.

As a high ranked civil servant in the Ministry of Economics, the "German Keynes" Wilhelm Lautenbach had proposed work creation programs to fight the economic crisis as early as in $1931{ }^{40}$ Stützel, who edited Lautenbach's work posthumously, carefully juxtaposed two versions of a proposal for deficit spending put forward in $1931 .{ }^{41}$ In the same bundle an article of $1936^{42}$ is reprinted in which Lautenbach discussed the multiplier of public investment. Through a saving ratio of one quarter the income effects "petered out" and thus Lautenbach got the rather high multiplier of four. ${ }^{43}$

In their textbook, published in 2013, Spoerer/Streb ${ }^{44}$ discuss this issue referring to Erbe ${ }^{45}: \mathrm{He}$ put forward a multiplier of 1.6 or 1.5 by comparing the increase of national income

\footnotetext{
36 "In contrast to the United States and Britain, fiscal policies undertaken by the Nazis helped to promote a quick and complete economic recovery from the Great Depression in Germany." Conclusion by Cohn 1992, p. 318.

${ }^{37}$ Overy (1982), however, did not stick to the work creation program proper, but evaluated the entire package of government policy ("particularly in construction, motorisation and rearmament") which stimulated the economy. On the importance of the "motor-car revolution" in particular, see Overy (1975).

${ }^{38}$ See also Spoerer (2005), who supports Buchheim against Abelshauser.

${ }^{39}$ Statistisches Reichsamt 1933.

${ }^{40}$ On Lautenbach, see Kroll 1958, pp. 379 ff.

${ }^{41}$ Lautenbach 1952, pp. $137 \mathrm{ff}$.

${ }^{42}$ In that year, Lautenbach worked in the StRA. In 1934, Schacht had kicked him out of his ministry of economics. See Fremdling 2015.

${ }^{43}$ The assumptions, however, are very restrictive: closed economy, additional production exclusively for intermediate and consumption goods (no private investment), no time for adjustment needed. Thus the money spent immediately created additional income. Lautenbach 1952, pp. $102 \mathrm{ff}$.

${ }^{44}$ Spoerer/Streb 2013, pp. $114 \mathrm{ff}$.

${ }^{45}$ Erbe 1958, pp. 163 ff.
} 
(Volkseinkommen) yielded by additional government spending between 1932 and 1936. His crude guestimate and references to similar rather speculative reasonings of other scholars led him to conclude, that the secondary effects of public investment had been very modest ("sehr gering"). Spoerer/Streb accept Erbe's reasoning, not the least because they assumed an exaggerated (textbook) Keynesian multiplier of five for government spending as yardstick when discussing the effects of NS-economic policy. It seems pretty clear, however, that empirically founded calculations of multipliers yielded significantly lower figures than textbook multipliers. ${ }^{46}$ In line with this reasoning, our multipliers (see last row of Table 4) comply with contemporary compilations by the StRA. We thus conclude that rather low multipliers (compared with textbook calculations) are no convincing argument against the impact of any governmental programs to stimulate work creation by deficit spending.

\section{A note on deficit spending}

We do not want to reopen the discussion as to what extent the NS-economic policy can be labelled as Keynesian in its nature. Ritschl (2003) neatly summarized this discussion and referred to the relevant literature. ${ }^{47}$ According to his findings, the NS-measures came too late and were too small to allow a Keynesian interpretation of the recovery process. He thus corroborates Erbe's findings, but rejects among others Overy's and Cohn's conclusions. ${ }^{48}$

One concern was, however, as to what degree work creation and rearmament had been financed by deficit spending. We can complement this aspect by referring to an archival source on this issue which we recently detected: in 1938 the Department VI Statistik der Umsatzverflechtung $^{49}$ of the StRA (currently it would have been labelled: Department of National Accounting and Input-Output Analysis) provided a preliminary (Entwurf) report for the Minister of Economics on Statistische Grundlagen für die Finanzierung der Volkswirtschaft (basic statistics on financing the economy) ${ }^{50}$ According to these figures (see Table 7) the government (public administration) increased its yearly borrowing, on balance by between one to more than four billion RM between 1933 and $1936 .{ }^{51}$ During the same period (until 1935) the private part of the German economy reduced its debt considerably, on balance by two and a half billion RM.

\footnotetext{
${ }^{46}$ See Thomas (1983) with moderate, but empirically founded, multipliers of government spending for Britain during the 1930s.

${ }^{47}$ On this, see among others in particular the classical study by Erbe (1958).

${ }^{48}$ Ritschl 2003, pp. 126-128.

${ }^{49}$ This department was in charge of the section "Volkswirtschaftliche Bilanzen" (national accounts) of the German statistical yearbooks (StJR).

${ }^{50}$ BA R 3102 2700, 19. 4. 1938.

${ }^{51}$ Erbe and an earlier estimate by Ritschl present significantly higher amounts (see Table VIII in Ritschl 1992, p. 166). Ritschl's revised figures for the central government (Reich) are, besides a slightly different timing, roughly the same for the years between 1933 and 1936 (Ritschl 2003, Tabelle 3: "Nettokreditaufnahme des Reichs").
} 
Table 7: Financing economic activity in Germany 1933-1936

m RM

\begin{tabular}{|c|c|c|c|c|}
\hline $\begin{array}{l}\text { Changing balance of borrowed funds } \\
\text { by borrowing* }(+) \text { or repayment of debt }(-)\end{array}$ & 1933 & 1934 & 1935 & 1936 \\
\hline Public administration & 991 & 2,556 & 3,912 & 4,357 \\
\hline Rest of the economy $* * *$ & $-2,050$ & $-1,445$ & -166 & 485 \\
\hline Sum & $-1,059$ & 1,111 & 3,746 & 4,842 \\
\hline \multicolumn{5}{|l|}{ by providing* $(+)$ or reclaiming $(-)$ credit } \\
\hline Private savings $* * * *$ & 1,056 & 1,739 & 2,578 & 3,766 \\
\hline Business firms & -376 & 2,351 & 1,792 & 2,796 \\
\hline Foreign countries $* *$ & $-1,739$ & $-2,979$ & -624 & $-1,720$ \\
\hline Sum & $-1,059$ & 1,111 & 3,746 & 4,842 \\
\hline Total long-term borrowing & $-1,142$ & 625 & 1,534 & 2,979 \\
\hline Total short-term borrowing & 83 & 486 & 2,212 & 1,863 \\
\hline Total borrowing & $-1,059$ & 1,111 & 3,746 & 4,842 \\
\hline
\end{tabular}

$*+$ sign in the original source

** including devaluation of foreign debt and "der Gewinne aus dem Skriptverfahren"

*** partly share issue ("davon Aktieemission") - "Kurswerte der gegen Bareinzahlung ausgegebenen Aktien aus Gründungen und Kapitalerhöhungen (ohne Banken und Versicherungen, deren Kapitalaufnahme in den übrigen Krediten schon gezählt ist)."

**** Spareinlagen, Versicherungen (Reinvermögen), Kauf von Wertpapieren, Kassenhaltung und Bankguthaben. Source: BA R3102 2700, 19.4.1938.

We do not know as to what extent these additional funds of the government were used for work creation, rearmament or public investment. ${ }^{52}$ It is remarkable, however, that between 1933 and 1935 the entire work creation program (aggregated 4.8 billion RM) as put forward in Table 3 was matched by deficit spending of the government (aggregated 7.5 billion RM). Government borrowing even contributed to financing the rearmament program by a substantial part. Above all, funds for increased government debt came from private savings held by banks and insurance companies as financial intermediaries. Not before $1934 \mathrm{did}$ business firms come to the forefront as a source of government borrowing through providing short term funds, probably by accepting Mefo-bills. ${ }^{53}$ Foreign creditors profited from increased repayment of debt. Partly their claims were merely reduced by devaluation of their currencies, however. Without the devaluations of the Anglo-Saxon countries and of the goldbloc in 1936 the debt of the German government would have had increased even more on balance. ${ }^{54}$

For 1936 we got the reliable figure on GDP of 83 billion RM (Fremdling/Staeglin $2014 \mathrm{a}, \mathrm{b}$ ): the 4.4 billion RM of public borrowing of that year made up more than five percent of GDP. Of course one can doubt whether this figure and comparable ones for the years before qualify to be labelled as "pronounced (ausgeprägtes) deficit spending" as Ritschl (2003, p. 133) put it. The fact of a deficit financed recovery-program as such is undeniable. The argument

\footnotetext{
${ }^{52}$ Financing public investment is the primary concern of Ritschl 1992.

${ }^{53}$ Mefo-bills were specific bills of exchange for financing military outlays, see Ritschl 1992, pp. 166 ff.; Ritschl 2003 , pp. 130 ff.; Oshima 2006.

${ }^{54}$ See footnote of the respective table and p. 3 of the text in BA R 31022700.
} 
should be based on the impact of these programs rather than on some kind of scholastic discussion on its nature: to be or not to be Keynesian. This impact is primarily an empirical question: and we tackled this issue as such - made possible by the now available input-output table of 1936.

\section{The impact of military spending on production and employment 1932-1939}

Spoerer and Streb rightly claim that the economic leaders of the NS-regime did not at all want to stimulate consumption by their work creation programs, they rather intended to channel the mobilized resources into increased armament. Work creation was thus accompanied by a highly restrictive wage and income policy and by campaigns to save earned money. ${ }^{55}$

These aims and measures of the German government of course went contrary to any type of Keynesian inspired economic policy and raises some doubts on our methodology to analyse this policy: the increasing preponderance of rearmament reveals the limitations of our model. This is based on fixed structural interdependencies of the German economy in 1936, clearly reflected in the Leontief matrix and its fixed input-output coefficients. According to our sectoral breakdown (see Table 4) agriculture would have profited overwhelmingly from the 2.5 billion RM the government spent on work creation in 1934: directly and indirectly induced production by 7.3 (D2) or 9.3 (D1) percent and directly and indirectly induced employment by 26 (D2) or 32 (D1) percent of the macroeconomic effects. Compared with agricultural employment and gross production in 1936 this would have made up 3.4 (D2) or 5.1 (D1) percent. Given the priorities of the regime and the performance of agriculture such an increase of production and employment in agriculture itself is not conceivable.

Degler/Streb (2008) clearly show that the agrarian sector under the NS-regime performed poorly in comparison with productivity gains before (Weimar period) or after the War in West Germany. Except for some increase of output agricultural performance did not match the selfimposed goals of the regime, it was rather a "lost battle for production (verlorene Erzeugungsschlacht)" ${ }^{56}$ On the other hand, prices of agricultural products were kept down by the state's price control. James concluded: “... cheap food after 1934/5 helped to sustain the growth of the 1930s." ${ }^{57}$ In any case our approach ${ }^{58}$ reveals that tight controls of the government were necessary to channel resources into those branches of the German economy which met the increasing demand for rearmament and thus fulfilled the aims of the regime.

For our published analysis of the impact of rearmament expenditure on production and employment in 1936 we used an aggregate version of the input-output table (Fremdling/Staeglin 2014 b). Here, we complement our previous results for 1936 and in addition, we extend the analysis to most of the other years of the 1930s by explicitly using the

\footnotetext{
${ }^{55}$ Spoerer/Streb 2013, pp. 116, 143 ff., 202 ff.; see also the contemporary publication by the StRA 1943.

${ }^{56}$ On the poor performance of agriculture, see also Fremdling/Staeglin 2014 a, pp. 225-227 and Fremdling 2010.

${ }^{57}$ James 1986, p. 357.

${ }^{58}$ Our input-output table and the consumption pattern reflect the structure of the German economy in the mid-1930s pretty well: without government intervention additional employment and additional income would have increased the demand for consumption goods. Prices would have risen if production of food had not kept abreast.
} 
comprehensive version of our input-output table detailed for 40 branches or sectors. Furthermore, we apply the Leontief model combined with the Keynesian multiplier. Table 8 presents our basic data on government expenditure in total and on military spending, in particular for the year 1936.

As explained in section III, the basic data of the input-output table had to be rearranged for applying the input-output analysis: to isolate the effects of rearmament, the government sector was split up into civilian (non-military) and military spending. Military expenditure thus became a separate vector of final demand. We applied our model by using the same matrix algebra and the same consumption function as for the work creation programs (see section V). Besides the adapted input-output table, we replaced the final demand by vectors of military spending. Table 9 shows the estimated impact of rearmament on the German economy in 1936.

Our calculation yielded the large direct and indirect impact (Leontief linkages) on the production of those industries closely associated (directly and indirectly) with arms production: vehicles and aerospace, basic iron and steel products, fabricated iron and steel products, chemical-technical industry and metal products and to lesser degree machinery. In these industries a fifth to a third of their labour force worked directly and indirectly for military purposes. Building and construction was the largest single sector profiting from rearmament (see Table 9). Constructional steel, machinery and vehicles are the sectors which directly produced armament (e. g. air planes, war ships, tanks, cannons etc.). In these industries the indirect Leontief linkages are much weaker than those on the iron and steel industry and non-ferrous metal production, which delivered the intermediate inputs for the specific armament industries and their suppliers. Construction or the building industry built barracks for soldiers and constructed new and extended naval ports, airports for the Luftwaffe (air force), bunkers and fortifications. ${ }^{59}$ The picture changes if employment and Keynesian multiplier effects are taken into account as well. Here "agriculture" comes to the forefront. The high share in induced employment was of course due to the low labour productivity (thus a high labour output ratio) of German agriculture. Furthermore the same pattern emerges as described in section $\mathrm{V}$ for work creation programs. The multipliers induced by military spending (see last row of Table 9) are higher than those for work creation. This is due to the fact that direct military spending involved nearly all branches of our input-output table.

In 1936 between four and five million work places directly and indirectly depended on the military budget, thus between 13 and 16 percent of total labour force in that year. Direct and indirect Leontief effects alone revealed that more than 12 percent of the industrial workers and in total, seven percent of the labour force in Germany were directly or indirectly engaged in armament production. As early as 1936, when the major impact of rearmament was still to come Germany's preparation for the war brought about these effects on employment.

\footnotetext{
${ }^{59}$ For the impact of rearmament on the British economy with similar leading sectors, see Thomas 1983. See now, however, the revisionist approach by Crafts and Mills 2013.
} 
Table 8: Government expenditure - Germany 1936

m RM

\begin{tabular}{|c|c|c|c|c|c|c|}
\hline Input & Government & $\begin{array}{c}\text { Adminis- } \\
\text { tration }\end{array}$ & Military & $\begin{array}{c}\text { Social } \\
\text { Security }\end{array}$ & Total & Investment \\
\hline 1 & Agriculture & 281.2 & 84.0 & 23.6 & 388.7 & \\
\hline 2 & Forestry, fishery & 4.6 & 3.9 & 1.1 & 9.6 & \\
\hline 3 & Mining & 26.2 & 27.0 & 24.9 & 78.1 & \\
\hline 4 & Fuel industries & 7.5 & 17.0 & 6.8 & 31.3 & \\
\hline 5 & Basic iron and steel products & 0.0 & 2.6 & & 2.6 & \\
\hline 6 & Non-ferrous metals & 0.0 & 1.8 & & 1.8 & \\
\hline 7 & Foundries & 0.0 & 0.0 & & & \\
\hline 8 & Fabricated iron and steel products & 100.1 & 555.9 & & 656.0 & 10.0 \\
\hline 9 & Machinery & 172.6 & 501.8 & 9.9 & 684.3 & 199.0 \\
\hline 10 & Constructional steel & 14.9 & 360.9 & & 375.8 & 179.0 \\
\hline 11 & Vehicles and aerospace & 37.4 & 991.4 & & $1,028.7$ & 119.0 \\
\hline 12 & Electrical engineering & 53.1 & 195.1 & 18.4 & 266.6 & 199.0 \\
\hline 13 & Precision engineering, optics & 25.4 & 62.6 & 10.7 & 98.7 & 60.0 \\
\hline 14 & Metal products & 10.5 & 330.5 & 13.3 & 354.3 & 99.0 \\
\hline 15 & Stone and quarrying & 9.0 & 10.8 & 1.5 & 21.3 & \\
\hline 16 & Ceramics & 2.2 & 2.8 & 1.1 & 6.1 & \\
\hline 17 & Glass & 3.0 & 2.8 & 1.1 & 6.9 & \\
\hline 18 & Saw mills, timber processing & 0.0 & 0.0 & & & \\
\hline 19 & Manufactured wood products & 47.1 & 53.5 & 8.9 & 109.5 & 129.0 \\
\hline 20 & Chemical industry & 32.9 & 19.1 & 207.9 & 259.9 & \\
\hline 21 & Chemical-technical industry & 0.0 & 242.5 & 9.6 & 252.1 & \\
\hline 22 & Rubber and asbestos manufacture & 9.7 & 30.9 & 3.9 & 44.5 & \\
\hline 23 & Manufacture of paper and paper products & 12.7 & 53.5 & 2.5 & 68.7 & \\
\hline 24 & Printing and duplicating & 44.1 & 14.3 & 12.2 & 70.6 & \\
\hline 25 & Leather industry & 7.5 & 12.9 & & 20.3 & \\
\hline 26 & Textiles & 9.0 & 42.9 & 9.6 & 61.5 & \\
\hline 27 & Clothing & 111.5 & 89.3 & 12.8 & 213.7 & \\
\hline 28 & Edible oil and fats & 0.0 & 5.0 & & 5.0 & \\
\hline 29 & Spirits industry & 0.0 & 10.0 & & 10.0 & \\
\hline 30 & Food, beverages and tobacco & 185.3 & 156.1 & 33.1 & 374.5 & \\
\hline 31 & Building and construction & 73.7 & $2,400.0$ & 39.2 & $2,512.9$ & $1,506.0$ \\
\hline 32 & Electricity, gas and water & 100.1 & 17.8 & 18.5 & 136.3 & \\
\hline 33 & Wholesale trade & 73.2 & 461.9 & & 535.1 & \\
\hline 34 & Retail trade & 23.2 & 130.5 & & 153.7 & \\
\hline 35 & Transport and communication & 121.1 & 470.3 & 21.6 & 612.9 & \\
\hline 36 & Banking and insurance & 49.3 & 0.0 & & 49.3 & \\
\hline 37 & Dwelling & 45.6 & 446.6 & 15.4 & 507.6 & \\
\hline 38 & Government & 0.0 & 122.2 & & 122.2 & \\
\hline 39 & Other services & 4.5 & 79.5 & 696.8 & 780.7 & \\
\hline 40 & Domestic services & & & & & \\
\hline $1-40$ & Domestic intermediate and final inputs & $1,698.0$ & $8,009.7$ & $1,204.3$ & $10,912.0$ & $2,500.0$ \\
\hline 41 & Imports & 14.0 & 75.0 & & 89.0 & 11.0 \\
\hline $1-41$ & Total intermediate and final inputs & $1,712.0$ & $8,084.7$ & $1,204.3$ & $11,001.0$ & $2,511.0$ \\
\hline 42 & Compensation of employees & $5,140.3$ & 597.3 & 414.8 & $6,152.4$ & \\
\hline 43 & Indirect taxes minus subsidies & & & & & \\
\hline 44 & Depreciation & 600.0 & & & 600.0 & \\
\hline 45 & Mixed income/operating surplus & & & & & \\
\hline $42-45$ & Gross value added (net production) & $5,740.3$ & 597.3 & 414.8 & $6,752.4$ & \\
\hline $1-45$ & Gross production & $7,452.3$ & $8,682.0$ & $1,619.1$ & $17,753.4$ & \\
\hline
\end{tabular}

Source: Fremdling/Staeglin 2014a, pp. $236 \mathrm{f}$. 
Table 9: Impact of military expenditure on production and employment in Germany 1936* $\mathrm{m} \mathrm{RM}$ and number of people employed

\begin{tabular}{|c|c|c|c|c|c|c|c|c|c|c|c|c|c|c|}
\hline & & \multirow{3}{*}{$\begin{array}{l}\text { Labour } \\
\text { output } \\
\text { ratio** }\end{array}$} & \multicolumn{4}{|c|}{ Induced production } & \multirow{2}{*}{\multicolumn{2}{|c|}{ Direct and indirect }} & \multicolumn{4}{|c|}{ Induced employment } & & \\
\hline & & & \multirow[t]{2}{*}{ Direct } & \multirow[t]{2}{*}{$\begin{array}{l}\text { Indirect } \\
\text { Leontief }\end{array}$} & \multirow{2}{*}{$\begin{array}{c}\text { Indirect } \\
\text { Keynes } \\
\text { D1 }\end{array}$} & \multirow{2}{*}{$\begin{array}{c}\text { Indirect } \\
\text { Keynes } \\
\text { D2 }\end{array}$} & & & \multirow[t]{2}{*}{ Direct } & \multirow[t]{2}{*}{$\begin{array}{l}\text { Indirect } \\
\text { Leontief }\end{array}$} & \multirow{2}{*}{$\begin{array}{c}\text { Indirect } \\
\text { Keynes } \\
\text { D1 }\end{array}$} & \multirow{2}{*}{$\begin{array}{c}\text { Indirect } \\
\text { Keynes } \\
\text { D2 }\end{array}$} & \multicolumn{2}{|c|}{ Direct and indirect } \\
\hline & & & & & & & D1 & D2 & & & & & D1 & D2 \\
\hline 1 & Agriculture & 770 & 84 & 97 & 1,942 & 1,274 & 2,123 & 1,455 & 64,641 & 74,577 & $1,494,610$ & 980,520 & $1,633,828$ & $1,119,738$ \\
\hline 2 & Forestry, fishery & 187 & 4 & 40 & 88 & 57 & 132 & 101 & 737 & 7,495 & 16,398 & 10,757 & 24,630 & 18,990 \\
\hline 3 & Mining & 160 & 27 & 236 & 206 & 135 & 469 & 399 & 4,324 & 37,780 & 32,948 & 21,615 & 75,052 & 63,719 \\
\hline 4 & Fuel industries & 39 & 17 & 68 & 0 & 0 & 85 & 85 & 666 & 2,680 & 0 & 0 & 3,345 & 3,345 \\
\hline 5 & Basic iron and steel products & 41 & 3 & 1,046 & 0 & 0 & 1,048 & 1,048 & 106 & 43,089 & 0 & 0 & 43,194 & 43,194 \\
\hline 6 & Non-ferrous metals & 43 & 2 & 314 & 0 & 0 & 316 & 316 & 77 & 13,514 & 0 & 0 & 13,591 & 13,591 \\
\hline 7 & Foundries & 162 & 0 & 204 & 0 & 0 & 204 & 204 & 0 & 33,034 & 0 & 0 & 33,034 & 33,034 \\
\hline 8 & Fabricated iron and steel products & 144 & 556 & 313 & 0 & 0 & 869 & 869 & 80,042 & 45,088 & 0 & 0 & 125,130 & 125,130 \\
\hline 9 & Machinery & 141 & 502 & 98 & 0 & 0 & 600 & 600 & 70,986 & 13,841 & 0 & 0 & 84,827 & 84,827 \\
\hline 10 & Constructional steel & 166 & 361 & 54 & 0 & 0 & 414 & 414 & 59,803 & 8,881 & 0 & 0 & 68,684 & 68,684 \\
\hline 11 & Vehicles and aerospace & 133 & 991 & 91 & 0 & 0 & 1,082 & 1,082 & 131,656 & 12,080 & 0 & 0 & 143,737 & 143,737 \\
\hline 12 & Electrical engineering & 134 & 195 & 98 & 17 & 11 & 310 & 304 & 26,113 & 13,135 & 2,219 & 1,456 & 41,467 & 40,704 \\
\hline 13 & Precision engineering, optics & 208 & 63 & 21 & 0 & 0 & 84 & 84 & 13,042 & 4,423 & 0 & 0 & 17,465 & 17,465 \\
\hline 14 & Metal products & 194 & 331 & 41 & 130 & 85 & 502 & 457 & 64,206 & 7,990 & 25,307 & 16,602 & 97,503 & 88,799 \\
\hline 15 & Stone and quarrying & 216 & 11 & 347 & 0 & 0 & 357 & 357 & 2,336 & 74,802 & 0 & 0 & 77,137 & 77,137 \\
\hline 16 & Ceramics & 269 & 3 & 11 & 36 & 23 & 49 & 37 & 756 & 2,838 & 9,560 & 6,272 & 13,155 & 9,867 \\
\hline 17 & Glass & 218 & 3 & 15 & 24 & 16 & 42 & 34 & 614 & 3,326 & 5,173 & 3,393 & 9,112 & 7,333 \\
\hline 18 & Saw mills, timber processing & 142 & 0 & 91 & 0 & 0 & 91 & 91 & 0 & 12,940 & 0 & 0 & 12,940 & 12,940 \\
\hline 19 & Manufactured wood products & 337 & 53 & 69 & 301 & 197 & 424 & 320 & 18,013 & 23,348 & 101,302 & 66,458 & 142,663 & 107,819 \\
\hline 20 & Chemical industry & 57 & 19 & 124 & 0 & 0 & 143 & 143 & 1,090 & $\begin{array}{r}r 3,080 \\
7,084\end{array}$ & 0 & $\begin{array}{r}00,450 \\
0\end{array}$ & 8,174 & 8,174 \\
\hline 21 & Chemical-technical industry & 69 & 242 & 49 & 156 & 103 & 447 & 394 & 16,631 & 3,330 & 10,721 & 7,034 & 30,682 & 26,994 \\
\hline 22 & Rubber and asbestos manufacture & 112 & 31 & 50 & 0 & 0 & 81 & 81 & 3,466 & 5,640 & 0 & 0 & 9,106 & 9,106 \\
\hline 23 & Manufacture of paper and paper products & 87 & 53 & 50 & 14 & 9 & 117 & 113 & 4,635 & 4,306 & 1,231 & 808 & 10,173 & 9,749 \\
\hline 24 & Printing and duplicating & 176 & 14 & 38 & 334 & 219 & 386 & 271 & 2,518 & 6,636 & 58,943 & 38,669 & 68,097 & 47,823 \\
\hline 25 & Leather industry & 210 & 13 & 14 & 348 & 228 & 375 & 256 & 2,693 & 3,022 & 72,962 & 47,866 & 78,677 & 53,581 \\
\hline 26 & Textiles & 145 & 43 & 134 & 711 & 467 & 888 & 643 & 6,242 & 19,425 & 103,452 & 67,868 & 129,119 & 93,536 \\
\hline 27 & Clothing & 269 & 89 & 9 & 616 & 404 & 714 & 502 & 24,059 & 2,426 & 165,889 & 108,830 & 192,374 & 135,314 \\
\hline 28 & Edible oil and fats & 22 & 5 & 41 & 223 & 146 & 269 & 193 & 111 & 922 & 4,958 & 3,252 & 5,991 & 4,286 \\
\hline 29 & Spirits industry & 37 & 10 & 34 & 59 & 39 & 103 & 83 & 370 & 1,249 & 2,189 & 1,436 & 3,808 & 3,055 \\
\hline 30 & Food, beverages and tobacco & 120 & 156 & 107 & 3,044 & 1,997 & 3,307 & 2,260 & 18,719 & 12,860 & 365,043 & 239,482 & 396,623 & 271,062 \\
\hline 31 & Building and construction & 190 & 2,400 & 163 & 0 & 0 & 2,563 & 2,563 & 455,899 & 30,912 & 0 & $\mid$ & 486,811 & 486,811 \\
\hline 32 & Electricity, gas and water & 53 & 18 & 271 & 189 & 124 & 478 & 413 & 935 & 14,252 & 9,968 & 6,540 & 25,155 & 21,726 \\
\hline 33 & Wholesale trade & 168 & 462 & 300 & 0 & 0 & 762 & 762 & 77,499 & 50,380 & 0 & 0 & 127,880 & 127,880 \\
\hline 34 & Retail trade & 441 & 131 & 28 & 89 & 58 & 247 & 216 & 57,506 & 12,140 & 39,161 & 25,691 & 108,807 & 95,337 \\
\hline 35 & Transport and communication & 159 & 470 & 530 & 101 & 67 & 1,102 & 1,067 & 74,599 & 84,074 & 16,082 & 10,550 & 174,755 & 169,223 \\
\hline 36 & Banking and insurance & 92 & 0 & 267 & 0 & 0 & 267 & 267 & 0 & 24,483 & 0 & 0 & 24,483 & 24,483 \\
\hline 37 & Dwelling & 8 & 447 & $\begin{array}{r}201 \\
95\end{array}$ & 0 & 0 & 541 & 541 & 3,773 & $\begin{array}{r}24,403 \\
801\end{array}$ & 0 & 0 & $\begin{array}{r}24,403 \\
4,574\end{array}$ & $\begin{array}{r}2,403 \\
4,574\end{array}$ \\
\hline 38 & Government & 189 & 122 & 134 & 37 & 24 & 293 & 281 & 23,101 & 25,417 & 6,930 & 4,546 & 55,447 & 53,064 \\
\hline 39 & Other services & 275 & 79 & 426 & 383 & 251 & 889 & 757 & 21,888 & 117,380 & 105,396 & 69,144 & 244,663 & 208,411 \\
\hline 40 & Domestic services & 974 & 0 & 0 & 0 & 0 & 0 & 0 & 0 & 0 & 0 & 0 & 0 & \\
\hline & Sum all groups & & 8,010 & 6,118 & 9,048 & 5,936 & 23,176 & 20,064 & $1,333,852$ & 861,601 & $2,650,443$ & \begin{tabular}{|l|}
$1,738,790$ \\
\end{tabular} & $4,845,895$ & $3,934,242$ \\
\hline & Multipliers & & & 0.76 & 1.13 & 0.74 & 2.89 & 2.50 & & 0.65 & 1.99 & 1.30 & 3.63 & 2.95 \\
\hline
\end{tabular}

Source: See text. 
First we focussed on the benchmark year of 1936. Then we extended our analysis of German rearmament by applying the same methodology to the entire decade of the 1930s, the crucial period before the outbreak of the Second World War: we drew on figures of military expenditure compiled by Oshima for the fiscal years 1932 to 1939 (Oshima 2006, p. 182). In order to assign this spending to the sectors of our input-output table we used the same percentage distribution as for the calendar year of 1936. In conformity with our model, the same procedure as for 1936 was applied to the military expenditure of each fiscal year. Table 10 shows the results of assessing the impact of rearmament on the German economy from 1932/33 to 1939. One has to keep in mind the hypothetical nature of the outcome: we applied the production structure, labour productivity and the structure of military spending we had estimated for 1936 to military spending before and after 1936.

Table 10: Impact of military expenditure on production and employment - Germany 1932-1939 $\mathrm{m}$ RM and number of people employed

\begin{tabular}{|c|c|c|c|c|c|c|c|c|}
\hline Fiscal year (april-march) & $1932 / 33$ & $1933 / 34$ & $1934 / 35$ & $1935 / 36$ & $1936 / 37$ & $1937 / 38$ & $1938 / 39$ & 1939* \\
\hline Military budget, m RM & 674 & 1,055 & 4,055 & 6,174 & 10,381 & 11,196 & 17,772 & 8,013 \\
\hline \multicolumn{9}{|l|}{ Induced production } \\
\hline Direct & 674 & 1,055 & 4,055 & 6,174 & 10,381 & 11,196 & 17,772 & 8,013 \\
\hline Indirect, Leontief model & 515 & 806 & 3,098 & 4,716 & 7,930 & 8,552 & 13,576 & 6,121 \\
\hline Indirect, Leontief model and Keynesian multiplier D1 & 1,276 & 1,998 & 7,678 & 11,690 & 19,656 & 21,199 & 33,651 & 15,172 \\
\hline Direct and indirect induced production D1 & 1,950 & 3,053 & 11,733 & 17,864 & 30,037 & 32,395 & 51,423 & 23,185 \\
\hline Indirect, Leontief model and Keynesian multiplier D2 & 1,014 & 1,588 & 6,103 & 9,291 & 15,623 & 16,849 & 26,746 & 12,059 \\
\hline Direct and indirect induced production D2 & 1,688 & 2,643 & 10,158 & 15,465 & 26,004 & 28,045 & 44,518 & 20,072 \\
\hline \multicolumn{9}{|l|}{ Induced employment } \\
\hline Direct & 112,241 & 175,689 & 675,279 & $1,028,156$ & $1,728,748$ & $1,864,470$ & $2,959,572$ & $1,334,405$ \\
\hline Indirect, Leontief model & 72,502 & 113,486 & 436,196 & 664,137 & $1,116,684$ & $1,204,354$ & $1,911,734$ & 861,958 \\
\hline Indirect, Leontief model and Keynesian multiplier D1 & 295,532 & 462,591 & $1,778,017$ & $2,707,145$ & $4,551,810$ & $4,909,168$ & $7,792,580$ & $3,513,501$ \\
\hline Direct and indirect induced employment D1 & 407,773 & 638,280 & $2,453,296$ & $3,735,302$ & $6,280,559$ & $6,773,638$ & $10,752,152$ & $4,847,907$ \\
\hline Indirect, Leontief model and Keynesian multiplier D2 & 218,818 & 342,512 & $1,316,481$ & $2,004,427$ & $3,370,256$ & $3,634,851$ & $5,769,790$ & $2,601,470$ \\
\hline Direct and indirect induced employment D2 & 331,060 & 518,201 & $1,991,760$ & $3,032,584$ & $5,099,005$ & $5,499,321$ & $8,729,362$ & $3,935,875$ \\
\hline
\end{tabular}

With this caveat in mind, we can draw the following conclusions: due to the reliance on the calibration year of 1936 the sectoral distribution of direct and indirect impact of rearmament on both production and employment is the same as described above for 1936. The multipliers for total production (2.5 (D2) or 2.9 (D1)) and employment (3.0 (D2) or 3.6 (D1)) are also the same for all these years. We thus consider only absolute impact figures on employment for the time span under question: in 1932/33 (fiscal year of 1932) barely 200 thousand people were engaged in armament industries directly and (Leontief) indirectly, as early as 1934/35 armament workers surpassed one million; and in the years 1936 and 1937 about three million people worked for military purposes. Shortly before the war nearly five million people were engaged in armament production (Table 10). ${ }^{60}$ Via the Keynesian multiplier, thus through additional income and consumption, significantly more jobs depended on military spending; shortly before the war between nine and eleven million.

In this paper, we have not yet considered public investment separately and for the whole time span before the war. This will be done in a following paper. There we will also assess the impact of the motorways (Reichsautobahnen), the very symbol of NS-success in fighting unemployment.

\footnotetext{
${ }^{60}$ According to Wagenführ (1963, p. 159) in 19392.4 million people worked directly in industrial production for the army. For the timing of rearmament, see also Abelshauser 1999, pp. $512 \mathrm{ff}$.
} 
Table 11: The impact of work creation programs and rearmament on employment - Germany 1933-1935 Number of people employed

\begin{tabular}{|c|c|c|c|}
\hline Year & 1933 & 1934 & 1935 \\
\hline \multicolumn{4}{|l|}{ Direct and indirect induced employment D1 } \\
\hline Work creation (calendar year) & 935,249 & $1,492,308$ & 482,261 \\
\hline Rearmament (fiscal year) & 638,280 & $2,453,296$ & $3,735,302$ \\
\hline Work creation and rearmament together & $1,573,530$ & $3,945,604$ & $4,217,563$ \\
\hline \multicolumn{4}{|l|}{ Direct and indirect induced employment D2 } \\
\hline Work creation (calendar year) & 758,086 & $1,217,776$ & 393,774 \\
\hline Rearmament (fiscal year) & 518,201 & $1,991,760$ & $3,032,584$ \\
\hline Work creation and rearmament together & $1,276,288$ & $3,209,537$ & $3,426,358$ \\
\hline
\end{tabular}

Source: See text and Tables 3, 10

\section{Evaluation - impact on employment}

Putting together the effects of both work creation proper and rearmament (see Table 11) demonstrates that more than one million jobs were created here as early as 1933 . They formed a substantial part of the German labour force. And in 1934 and 1935, even three to four million people were employed in this manner. Several hundred thousand and later millions of jobs profited from the additional income spent on consumption. In the years from 1936 onwards, the enormous increase to five million and more for armament production alone was accompanied by additional employment and measures to restrict additional consumption. Although we did not discuss other means of public investment, the steep rise of public spending, regardless of the questionable purposes, suggests a larger impact on employment than recent historical research maintained. ${ }^{61}$ The more so if we ignored the agricultural sector with its oversized work force and the notoriously extremely low productivity and if we considered the industrial part of the German economy separately, instead.

Of course one can speculate about a counterfactual scenario as has been put forward by Ritschl: "An upswing ... would have had exactly the same vigor without Hitler and without deficit spending." It is true that the turning point of the business cycle had been passed in 1932, thus before Hitler had become chancellor and maybe it is also true that work creation programs and rearmament were not a necessary condition to achieve full employment as early as 1936/37. On basis of our reassessment, however, we can safely claim that they were a sufficient condition for this purpose.

The substantial increase of people employed through work creation programs and subsequently bound for rearmament surely helped the German economy in driving towards full employment: whereas in 1933 on a yearly average 4.8 million people were registered as unemployed with peaks in January and February of about six million (see StJR 41/42, p. 426) this figure dropped to 1.6 million unemployed (StJR 41/42, p.426) in 1936 and to negligible proportions thereafter.

In more general terms, our reassessment rather supports the former view put forward, e. g. by Overy that the NS-regime introduced "a wide range of government policies designed to

\footnotetext{
${ }^{61}$ For a summary of the discussion, see Spree (2004), Spoerer (2005) and Spoerer/Streb (2013, pp. 114 ff.).
} 
augment and speed up the existing recovery" (Overy 1982, p. 65). We would, however, modify his chronology, that rearmament became increasingly important from 1936 onwards: ${ }^{62}$ rearmament actually gathered momentum as early as 1934 .

\section{Acknowledgements}

We are grateful for the possibility of using the infrastructure of DIW Berlin.

\section{Sources and literature}

Archival material:

Bundesarchiv - Federal Archive of Germany (BA)

Statistisches Reichsamt BA R3102 2700

\section{Statistical compilations:}

Statistisches Jahrbuch für das Deutsche Reich (StJR), 1933, 1934, 1935, 1936, 1937, 1938, $1939,1941 / 42$

Statistisches Reichsamt (1935), Die Investitionen der deutschen Volkswirtschaft 1924 bis 1934, in: Wirtschaft und Statistik, 1935/18, pp. 688-691 (StRA 1935).

Länderrat des Amerikanischen Besatzungsgebiets (1949), Statistisches Handbuch von Deutschland 1928-1944, München: Franz Ehrenwirth-Verlag (StH1949).

\section{Literature:}

Abelshauser, Werner (1999), Kriegswirtschaft und Wirtschaftswunder, in: Vierteljahrshefte für Zeitgeschichte, 47, pp. 503-538.

Albert, Ursula (1956), Die deutsche Wiederaufrüstung der Dreißiger-Jahre als Teil der staatlichen Arbeitsbeschaffung und ihre Finanzierung durch das System der Mefowechsel, Diss. Nürnberg.

Boelcke, Willi A. (1985), Die Kosten von Hitlers Krieg, Paderborn: Ferdinand Schöningh.

Borchardt, Knut (1984), Wege aus der Arbeitslosigkeit: Die Diskussion in Deutschland in den frühen dreißiger Jahren, in: Vierteljahrshefte zur Wirtschaftsforschung, pp. 6-16.

Buchheim, Christoph (2008), Das NS-Regime und die Überwindung der Weltwirtschaftskrise in Deutschland, in: Vierteljahrshefte für Zeitgeschichte, pp. 381-414.

Cohn, Raymond L. (1992), Fiscal Policy in Germany during the Great Depression, in: Explorations in Economic History, 29, pp. 318-342.

\footnotetext{
${ }^{62}$ Overy (1982, p, 65) reads: „Before 1936 the bulk of the expenditure was on work-creation, motorisation and general construction. After 1936 rearmament became increasingly important,"
} 
Crafts, N. and Mills, T. C. (2013), Rearmament to the Rescue? New Estimates of the Impact of "Keynesian" policies in 1930s` Britain, in: Journal of Economic History, 73, pp. 10771104.

Degler, Stephanie and Streb, Jochen (2008), Die verlorene Erzeugungsschlacht: Die nationalsozialistische Landwirtschaft im Systemvergleich, in: Jahrbuch für Wirtschaftsgeschichte - Economic History Yearbook, pp. 161-181.

Erbe, Réne (1958), Die nationalsozialistische Wirtschaftspolitik 1933-1939 im Lichte der modernen Theorie, Zürich: Polygraphischer Verlag.

Fremdling, Rainer (2007), German Industrial Employment 1925, 1933, 1936 and 1939. A New Benchmark for 1936 and a Note on Hoffmann's Tales, in: Jahrbuch für Wirtschaftsgeschichte - Economic History Yearbook, pp. 171-195.

Fremdling, Rainer (2010), German Agricultural Employment, Production and Labour Productivity: A New Benchmark for 1936 and a Note on Hoffmann's Tales, in: Jahrbuch für Wirtschaftsgeschichte - Economic History Yearbook, pp. 215-228.

Fremdling, Rainer (2015), Wirtschaftsstatistik 1933-1945, in: Ritschl, Albrecht (ed.) (forthcoming).

Fremdling, Rainer and Stäglin, Reiner (2013), Reconstruction of an Input-Output Table for Germany in 1936: Conceptual and Empirical-Statistical Problems, in: Institut für Wirtschaftsforschung Halle-IWH (ed.), Neuere Anwendungsfelder der Input-Output-Analyse, Halle: IWH 2013, 19-30.

Fremdling, Rainer and Staeglin, Reiner (2014 a), An Input-Output Table of Germany in 1936: A Documentation of Results, Sources and Research Strategy, in: Jahrbuch für Wirtschaftsgeschichte - Economic History Yearbook, pp. 187-298.

Fremdling, Rainer and Staeglin, Reiner (2014 b), Output, national income and expenditure: An input-output table of Germany in 1936, in: European Review of Economic History, 18, pp. 371-397.

Fremdling, Rainer and Staeglin, Reiner (2015), Work creation and rearmament in Germany 1933-1938 - A revisionist assessment of NS-economic policy based on input-output analysis (GGDC) Research Memorandum Nr. 152: http://www.rug.nl/research/ggdc/publications/iframes/research-memoranda

Gierth, Erich (1941), Aufbau und Methode der Industrieberichterstattung, in: Allgemeines Statistisches Archiv, 30, S. 294-301 (BA R3 25 F 17-22).

Grebler, Leo (1937), Die deutsche Arbeitsbeschaffung 1932-1935, in: Internationale Rundschau der Arbeit, 15, pp. 416-435, 816-832.

Holtfrerich, Carl-Ludwig (1992), Review of: James, Harold, Deutschland in der Weltwirtschaftskrise 1924-1936, Stuttgart: DVA 1988, in: Historische Zeitschrift, 255, pp. 498-501.

Institut für Konjunkturforschung (1935), Die Beschäftigung Anfang Herbst 1935, in: Wochenbericht, 8, Nr. 37, pp. 151-153. 
James, Harold (1986), The German Slump: Politics and Economics, 1924-1936. Oxford: OUP.

Klein, Burton (1948), Germany's Preparation for War: A Re-Examination, in: The American Economic Review, 38, pp. 56-77.

Kroll, Gerhard (1958), Von der Weltwirtschaftskrise zur Staatskonjunktur, Berlin: Duncker \& Humblot.

Kruedener, Jürgen von (ed.) (1990), Economic Crisis and Political Collapse, The Weimar Republic 1924-1933, New York: Berg Publishers.

Lautenbach, Wilhelm (1952), Zins, Kredit und Produktion (hg. Von Wolfgang Stützel), Tübingen: J. C. B. Mohr (Paul Siebeck).

Oshima, Michiyoshi (2006), Von der Rüstungsfinanzierung zum Reichsbankgesetz 1939, in: Jahrbuch für Wirtschaftsgeschichte - Economic History Yearbook, pp, 177-217.

Overy, R. J. (1975), Cars, Roads, and Economic Recovery in Germany, 1932-8, in: Economic History Review, 28, pp. 466-483.

Overy, R. J. (1982), The Nazi Economic Recovery 1932-1938, Houndmills: MacMillan.

Patel, Kiran Klaus (2005), Soldiers of Labor, Labor Service in Nazi Germany and New Deal America, 1933-1945, Cambridge: CUP.

Petzina, Dieter, Abelshauser, Werner and Faust, Anselm (1978), Sozialgeschichtliches Arbeitsbuch III, Materialien zur Statistik des Deutschen Reiches 1914-1945, München: Beck.

Ritschl, Albrecht (1992), Über die Höhe und Struktur der gesamtwirtschaftlichen Investitionen in Deutschland 1935-38, in: Vierteljahrschrift für Sozial- und Wirtschaftsgeschichte, 79, pp. 156-176.

Ritschl, Albrecht (2002), Deutschlands Krise und Konjunktur 1924-1934 - Binnenkonjunktur, Auslandsverschuldung und Reparationsproblem zwischen Dawes-Plan und Transfersperre (Jahrbuch für Wirtschaftsgeschichte, Beiheft 2), Berlin: Akademie Verlag.

Ritschl, Albrecht (2003), Hat das Dritte Reich wirklich eine ordentliche Beschäftigungspolitik betrieben? in: Jahrbuch für Wirtschaftsgeschichte, pp. 125-140.

Schiller, Karl (1936), Arbeitsbeschaffung und Finanzordnung in Deutschland, Berlin: Junker und Dünnhaupt.

Schröder, Susanne (1996), Steuerlastgestaltung der Aktiengesellschaften und Veranlagung zur Körperschaftssteuer im Deutschen Reich und den USA von1918 bis 1936. Berlin: Duncker \& Humblot.

Silverman, Dan P. (1998), Hitlers Economy. Nazi Work Creation Programs, 1933-1936, Cambridge Mass.: Harvard UP.

Spoerer, Mark (2005), Demontage eines Mythos? Zu der Kontroverse über das nationalsozialistische „Wirtschaftswunder““ in: Geschichte und Gesellschaft 31, pp. 415-438. 
Spoerer, Mark und Streb, Jochen (2013), Neue deutsche Wirtschaftsgeschichte des 20. Jahrhunderts, München: Oldenbourg.

Spree, Reinhard (2004), Wirtschaftliche Lage und Wirtschaftspolitik (Beschäftigungspolitik) in Deutschland am Beginn der NS-Herrschaft, in: Bayerische Landeszentrale für politische Bildungsarbeit (ed.), Die Anfänge der Braunen Barbarei, München: pp. 101-126. http://epub.ub.uni-muenchen.de/archive/00000382/01/ns-abNEU.pdf

Syrup, Friedrich (1936), Der Arbeitseinsatz und die Arbeitslosenhilfe in Deutschland, Berlin: Otto Elsner Verlagsgesellschaft.

Stäglin, Reiner and Pischner, Rainer (1976 a), Darstellung des um den Keynes'schen Multiplikator erweiterten offenen statischen Input-Output-Modells, in: Mitteilungen aus der Arbeitsmarkt- und Berufsforschung, Heft 3/1976, pp. 345-349.

Stäglin, Reiner et al. (1976 b), Multiplikatorwirkungen des Konjunkturprogramms von 1975, Anwendung des um den Keynes'schen Multiplikator erweiterten Input-Output-Modells (Deutsches Institut für Wirtschaftsforschung, Beiträge zur Strukturforschung, Heft 45), Berlin: Duncker \& Humblot.

Stäglin, Reiner (2013), Gross Fixed Capital Formation in the German Empire: An Investment Matrix for 1936, Jahrbuch für Wirtschaftsgeschichte - Economic History Yearbook, pp. 189202.

Stäglin, Reiner and Fremdling, Rainer (2015), Expertise zum Projekt Wirtschaftsforschung und wirtschaftspolitische Beratung im Spiegel der Zeit - Archivgestützte Recherchen über das IfK/DIW von 1925 bis 1945, Berlin: DIW (in Vorbereitung).

Statistisches Reichsamt (1933), Auswirkungen der unmittelbaren Arbeitsbeschaffung, in: Sonderbeilage zu Wirtschaft und Statistik, 13, Nr. 21, pp. 2-8. (As well Supplement to the letter of the president of the Statistical Office to the Minister of Economics, 19. 4. 1938, on "Statistical fundamentals of financing the economy" (Statistische Grundlagen für die Finanzierung der Volkswirtschaft), BA (German Federal Archive) R3102 2700).

Statistisches Reichsamt (1938), Der Reichsarbeitsdienst in den Jahren 1935 bis 1937, in: Wirtschaft und Statistik, 18, pp. 126-30.

Statistisches Reichsamt (1943), Die deutsche Arbeitspolitik in den letzten 10 Jahren, in: Wirtschaft und Statistik, 23, pp. 53-58.

Stelzner, Jürgen (1976), Arbeitsbeschaffung und Wiederaufrüstung 1933-1936, Nationalsozialistische Beschäftigungspolitik und Aufbau der Wehr- und Rüstungswirtschaft, Diss. Tübingen.

Thomas, Mark (1983), Rearmament and Economic Recovery in the late 1930s, in: The Economic History Review, 36, pp. 552-579.

Wagemann, Ernst (Hg.) (1935), Konjunkturstatistisches Handbuch 1936, Berlin: Hanseatische Verlagsanstalt Hamburg.

Wagenführ, Rolf (1963), Die deutsche Industrie im Kriege 1939 - 1945, Berlin: Duncker \& Humblot. 